\title{
The Economic Factors of Palestinian Al-Aqsa Uprising
}

\author{
Huiping Liu \\ College of Marxism, Qufu Normal University \\ No. 80, Yantai Road, Rizhao 276826, Shandong, China \\ Tel: 86-633-398-1533Ｅ-mail: zhang2002m@126.com
}

\begin{abstract}
Israel controlled the main productive factors in the West Bank of Jordan River and Gaza Strip. The Palestinian self-government had to dependence on the Israeli economy. At the same time Israel implemented sanctions on the Palestinian self-government which increased the economic pressures at the same time. Israeli controlling made the Palestinian domestic market become narrower. These economic factors changed Gaza into a hotbed of anti-Israeli struggle.
\end{abstract}

Keywords: Economic factors, The Palestinian, Al-Aqsa uprising

In September 2000, the Palestinian who lived in the West Bank and Gaza Strip uprised again after the first launched in 1987 against Israel. When we analysis the reasons for the uprising in 2000, we can see the political factors were the paramount reason among all the reasons. However, economic factors included Palestinian regional economic conditions, changes in people's living standards as well as economic relations between Israel and Palestine, especially since the establishment of the Palestinian National Authority, also played an important role in the outbreak of the uprising.

Palestine and Israel signed "Declaration of Principles" in 1993 and "Israeli-Palestinian Economic Memorandum" in 1994 and the "transitional agreement" in 1995 Since the Oslo peace process began. These agreements developed a sound framework for the running of the Palestinian economy, especially for the relations with Israel's economy, so that the Palestinians had some right in economic decision-making. However, in essence, Israel's complete control of the Palestinian economy and the Palestinian serious dependence on the Israeli economy was still not been adequately changed .There was a long way from the economic autonomy to territorial self-government.

\section{Palestinian economic dependence on the Government of Israel}

Land and water was a basic living material and it was also the main source of material wealth of society. The scarcity of land and water would be bound to seriously impede economic development. Israel continued to control these key productive factors which were not only the historically inertial development, but also the Israeli strategic decisions.

In order to solve Palestinian-Israeli issue, The PLO and the Israeli government signed the "Declaration of Principles on Interim Self-Government Arrangements," namely "Oslo agreement" after a long and arduous negotiations on September 13, 1993, But it was only a framework agreement .Then in order to carry out "Oslo agreement", the two sides signed the "Cairo Agreement" "on the Gaza Strip-Jericho first implementation agreement of self-government " "Taba Agreement" "Wye River accord" "Sharm el-Sheikh Memorandum ". These agreements prescribed the range and the time Israeli withdrew from the occupied territories step by step. But Israel was reluctant to withdraw unconditionally for economy and security, so that it delayed purposely. Israel withdrew from only 40 percent of the territorial area of the West Bank until 1999; even so, Palestinian government controlled entirely only 18.2 percent. After that, Sharon government refused to give up sovereignty in the West Bank, but calling for the entire sovereignty in West Bank and Gaza Strip. Sharon completely ignored the Palestinian autonomy and resorted to military force for invading Jenin, the Greek Bohlen, Bethlehem and other Palestinian-controlled areas again and again. Israel always advanced trenchant terms in the bargaining when it gave up the land each time. E.g. in Jericho, the Palestinian demanded 340 square kilometers, and Israel only gave 27 square kilometers. The Palestinian strongly protested, in the end Israel gave only 56 square kilometers. Moreover, Israel had Jericho firstly self-rule also in order to do its best to maintain the status quo of the West Bank and occupy it permanently because firstly implementing self-rule of Jericho had a symbolic significance in the West Bank. In addition, the PLO institutions would be moved here after Jericho implemented self-rule firstly and formed a de facto administrative center of the PLO, so that PLO would have to give up East 
Jerusalem. Israel did so when it gave up other land.

There was most of the plateau in Israel. Its general height was from 600 meters to 1000 meters above sea level and had a subtropical Mediterranean climate. Most of water was from Jordan River because of lack of rainfall, dry weather, and severe water shortage. Israel controlled the West Bank of Jordan River so it had the security assurances in water after 1967. Statistics show that the Israeli $1 / 3$ all water and nearly $1 / 2$ drinking water came from the West Bank groundwater, while Palestinians only got 25 percent of the total ground water each year. More than 100 million Palestinians in water only accounted for 1/3 to 10 million Jews water in the West Bank, so the distribution was very unfair. Palestinian authorities demanded increasing 28 million cubic meters water for the Palestinian side each year in the second phase of negotiations between Palestinian self-government and Israel. There was additional provision for Palestinian If they dug a new well. First of all, the Palestinian Water Resources Management Committee submitted its project proposal to the Israeli-Palestinian Joint Water Committee. The Israel technical branch of the Committee reviewed the proposal, and then sent it to Israel Hydrology Bureau. Israel Hydrology Bureau examined the well whether it would affect the hydrological situation in the territory; if approved, the proposal was sent back to the Joint Water Commission again. The Committee held a plenary meeting and discussed. Generally speaking, Palestinian got the project of ratification of the Palestinian-controlled areas and the Palestinian-Israeli co- controlled area in the "Transitional Agreement". At present, the Palestinians only drilled 5 new wells in the West Bank since the Madrid peace process. The Palestinian man-years per capita water consumption was only 85 cubic meters in the West Bank and Gaza while Israel was as much as 447 cubic meters. The Palestinian life and production lacked water seriously. Israeli Prime Minister Benjamin Netanyahu had repeatedly rebuked the Palestinian to launch sewage uprising and threatened to cut off the supply of fresh water to the Palestinian of the West Bank because the Palestinian had no funds for the sewage disposal system. Barak and Sharon government both insisted on adopting hard-line position about the water resources.

Israel continued to control land and water resources, weakening the Palestinian government's economic sovereignty. Palestinian people had nothing after loss of land and water resources, and self-government were unable to create new employment; they were forced to serve as cheap labor in Israel, they made great contributions for Israel's economic development. However, the Palestinian dreamed of separation from the Israeli economy and obtained the right of economic independence. The Israeli rulers had smashed their dreams once again. Palestinian peace process did not make the people out of the plight. On the contrary, a growing number of Palestinians worked in Israel in order to survive. The number of Palestinian workers in Israel was more than 25 million since 2000, and hit a high record since 1970. (Andre, 2000, p.24).Palestinian dependence on Israel had not decreased, but even more serious.

\section{The Economic Pressure of the Palestinian Self- controlled Area}

Israeli had ruled the West Bank and Gaza Strip for nearly 30 years. The Palestinian economy was constrained by the Israeli occupation so that it showed strong colonialism. Its industrial base was poor, or even that there was no decent industry. Industry accounted for only 8 percent in the gross national product; in agriculture, Israel prevented the Palestinians from planting citrus, only allowing them to grow some vegetables, such as strawberries and flowers avoiding competing with Jewish farmers. In the Gaza Strip, the cultivation area of citrus fruits reduced from 80000 dunums in 1967 to 43000 dunums in 1996, which led to a reduction of income of local residents. The Palestinian economy was mainly services and export of labor for Israel. About 1/3 of the Palestinian labor in the West Bank and Gaza came to work in Israel before "Oslo Agreement" was signed. Some of them engaged in the occupations which didn't need specialized technical and advanced vocational qualifications. Most of them worked in the construction industry. The economic factors became Israeli card that forcing Palestinian to submit in the peace talks Since the Palestinian National Authority established formally. Israel adopted blockade and sanctions after the violent attacks which not only increased the Palestinian government's economic pressures, but also aggravated the inherent tensions between Palestine and Israel. Israel's blockade had three forms: a general blockade, full blockade es and internal blockade. General blockade of Israel restricted Palestinian labor and goods flowing in the Palestinian and Israeli territory, between the Gaza Strip and the West Bank, between the North and the South in the west bank, between the West Bank and Jerusalem; full blockade referred to a total ban on Palestinians flowing in the above-mentioned areas; internal blockade that prevented Palestinians from flowing in Palestinian living regions of the West Bank. Blockade as the collective punishment against Palestinians essentially, resulting in the Palestinian autonomous region's economic deterioration. Israel's frequent blockade brought many difficulties and serious damage to Palestinian self-rule area. The main manifestations were:

First of all, the number of workers entering Israel reduced quickly, so that the revenue of the Palestinian people 
reduced and thus some families were in hardship. The numbers of Palestinian workers in Israel were about 116,000 in 1992, and then decreasing year by year, in 1996 fell to 36000. (Andre, 2000, p.24).In the meantime, the income of Palestinians also reduced during 1992-1995.The earnings of Palestinian workers had decreased by about 90 percent, from 741 million U.S. dollars fell to 70.5 million U.S. dollars. (Saudi, 1997, p.12).And more serious result for the Palestinian workers was the direct drop in living standards. Palestinian per capita incomes declined by 17 percent during 1994-1996. The poor that their income was less than 2.1 U.S. dollars daily were as high as 37.2\% in Gaza Strip, and the West Bank was about 15.4 percent in 1998. (Andre, 2000, p.23).About 21\% of Palestinians lived below the poverty line in the entire autonomous region in 2000. (Gene, 2001 Gene, p.13).As the number of workers entering Israel reduced, the Palestinian people's unemployment rates were constantly raising, and about 5 percent in 1993, up to 28.4 percent in May 1996. (Andre, 2000, p.23). The main reason was the Israeli blockade. High unemployment rate was proportional to the length of the blockade time.

Second, Israel's frequent blockade and closure of "boundary" limited the flowing of Palestinian commodity and goods, so that Palestinian economy suffered a great loss of millions of dollars and made the Palestinians most of the factory's production into a standstill. Israel had a month-long blockade in Bethlehem, leading to the loss of up to 12 million U.S. dollars in August 1997. The blockade caused damage amounting to 280 million U.S. dollars from 1993 to 1996. It was equivalent to twice the amount of aid to Palestinian in the same period. (Andre, 2000 , p.23).In other words, the international aid was less than the losses caused by the embargo and so not to mention to use this money to develop its economy. Palestinian per capita gross national product fell from 2684 U.S. dollars in 1992 to 1896 U.S. dollars in 1999. (Andre, 2000, p.33).

All in all, Palestinian living standard was declining and the Palestinian autonomous region's economic situation was deteriorating, which made the Palestinian against Israel spontaneously. Hamas provided economic subsidies for the public when the blockade brought Palestinian living into difficult situation, so Hamas expanded its political influence effectively. On the contrary, the influence of Yasser Arafat and other advocator of peace were weakened and advocators of military forces were on the rise. This provided a fertile ground and impetus for the uprising. Arafat said that there would be "hunger riots" if the unemployment problem was not resolved

\section{There was a Small Scale of Market in Palestinian Autonomous Area.}

In economic development, markets could provide the necessary factors of production. The faster the economy developed, the stronger it relied on the market. The economy could not develop without the market. In Palestine, Israeli controlled the roads and border route way (autonomous regions leading to Jordan, Egypt and Israel's roads), which made the Palestine-controlled area become the isolation belt. The Palestinian autonomous regions were divided into many small "enclave", as if the leopard spots scattered. In these enclaves, the market had small scale, less than 2 square kilometers, and making Palestinian market narrower. These enclaves had reached 227 till November 1999. The manufacturer had to change export-oriented large-scale production into small-scale production inefficiently in the enclave. The hope of Palestinian autonomous region's economic diversification and industrialization vanished like soap bubble. The Palestinian industrial output accounted for less than $15 \%$ of GDP in 1998. The agriculture was more fragile, and the trade fell by 22 percent from 1992 to 1996 in the West Bank and Gaza Strip. (Andre, 2000, p.25).In Palestine narrow market, Israel let itself any goods freely enter the Palestinian territory, while Palestinian self-government could only import food, agricultural products (not including fresh fruits and vegetables), infrastructure materials, fertilizer, household electrical appliances from other countries other than Israel. Among them, infrastructure materials, fertilizer, household electrical appliances must imported from Jordan or Egypt, the other species could import from the two above countries and other countries. The majority of such products were still from Israel in fact because the household electrical appliances of Egypt and Jordan had poor quality. On the export side, autonomous regions' market had only Israel where set up numerous barriers. The amount of goods that autonomous regions exported to Israel increased from 80 percent in 1980's to 96 percent in 1998. (Andre, 2000, p.23). This fully indicated that Palestinian self-government had over-reliance on the Israeli market. The Israel imported Palestinian goods which must be consistent with Israel's environment, health, health, safety and other standards, in particular vegetables, poultry and egg and so on .These food products had higher standard. Overall, trade between Palestine and Israel was not balanced. The Palestinian side had a huge trade deficit in 1996. Palestinian amount of exportation to Israel was only 300 million U.S. dollars, while the import amount was 15 billion dollars. (Saudi, 1997, p.12).To date, this situation hadn't been approved.

Israel relaxed the control over the Palestinian's economy after the signing of "Oslo Agreement" and "the Paris Economic Protocol". In essence, Israel pinched the Palestinian neck in the circulation of commodities and labor by controlling the roads and border route way, so that the economy of Palestinian self-rule areas was continually controlled by Israel. This was bound to cause Palestinian disappointment and dissatisfaction. 


\section{Conclusions}

Before and after autonomy, 70 percent of the Palestinians in Gaza supported the Palestinian-Israeli Agreement because they believed that they could finally get rid of Israeli economic oppression and live a better life. However, the self-government in Gaza constructed the infrastructure from zero, Israel's closure policy and international aid money paid lip service to the self-government, together with the hard-pressed financial situation of self-government, all these made it unable to be out of poverty situation fastly and approved the situation of falling living standards despite the Palestinians made arduous efforts. According to statistics, Gaza and autonomous regions' per capita income dropped from 900 U.S. dollars to 450-500 U.S. dollars in March 1995. (Rex, 1991, p.46).37.2\% of the population in Gaza lived below the poverty line by 1998. Even during the economic upturn, the poor still accounted for $1 / 3$ of total population in 2000. (Andre, 2000, p.23).Living became very difficult and the sound of complain filled with the autonomous regions. The good wishes of people lost once again. The number of supporting the Israeli-Palestinian Agreement had been reduced, and that of the support armed struggle increased.

Looking at years of the peace process, it did not bring much benefit to the Palestinian public. The autonomous regions and economy was still not fully independent; on the contrary, the economy (especially trade and labor).was still heavily dependence on Israel. Israel's frequent blockade caused the deterioration of Palestinian economy and the people's living standards declining and the widespread popular discontent to the Palestinian government. Hani Hassan who was a senior member in "Fatah" said that the Palestinian-Israeli negotiations were completely subservient to Israel's demands and strength. It would not have economic development but end the occupation. Palestinian nationalism urged that the Palestinians must adhere to anti-Israeli struggle and persist in the development of economic independence. That was the voice of the majority masses of the Palestinian people.

The Israeli right-wing leader Ariel Sharon came to "visit" Jerusalem's holy Al-Aqsa mosque in September 2000. The provocative act had been looked as the fuse, and the Palestinian people erupted into large-scale uprising once again, resulting in a serious bloodshed. Even today, the conflict still had not been properly settled. The large-scale uprising made the economic factors prominent. We can say that there would be no Palestinian economic development if no end to the occupation. There would be no real peace between Palestinians and Israelis. It was necessary to develop the Palestinian economy and improve people's life and provide material guarantee for peace in order to consolidate the results of Israeli-Palestinian peace talks which required not only Palestinian government's efforts, but also the international community, particularly Israel's utmost cooperation and support.

\section{References}

Andre Rigly. (2000). Living the Intifada. Middle East Report.

Gene Shap. (2001). The Intifada and Nonviolent Struggle. Journal of Palestine Studies, Summer.

Rex Brynen. (1991). Echoes of the Intifada, Regional Repercussions of the Palestinian-Israeli Conflict. Westview Press.

Saudi Arabia. (1997). The Palestine Uprising in the West Bank and Gaza Strip. Middle East Post, 15 July 1997. 